UDC 657.37

DOI 10.35433/ISSN2410-3748-2019-2(25)-1

Botsian Tetiana

PhD, Associated professor

Department of Economics, Management and Administration

Zhytomyr Ivan Franko State University

Ukraine

\title{
CORPORATE SOCIAL RESPONSIBILITY AND CORPORATE FINANCIAL PERFORMANCE: RELATIONSHIPS IN DIFFERENT COUNTRIES
}

This study aims to examine literature about relationship between corporate social responsibility (CSR) and financial performance (CFP) in different countries. The studies from nine different countries were examined. The results indicate that there are three groups of results. Three different types of relationships between CSR and CFP can be identified: positive, negative and neutral. We claim, that researchers of 9 different countries use quite the same methodology to different to examine the relation between CSR and CFP for different types of companies. However, CSR is strongly influenced by cultural and socio-economic environments and relates to a country's national business system. Political institutions are potential drivers of CSR as well. Moreover, informal institutions such as national cultures

have an important effect on CSR practices. The national business system of the specific country creates the conditions under which corporations are more or less likely to engage in socially responsible behavior. For instance, in countries with a high degree of union power, firms perform better on the social and environmental scores. So, variety of legislative basis and national institutions (political, market, cultural) are drivers of CSR. They is a specific for each country. Due to that, all examined studies are incomparable because of the national institutions' difference that drive responsible behavior of the companies. The results in one

country can differ in another. This article adds to the previous research devoted to the

relationship between CSR and CFP. Firstly, the study enhances understanding of the relationship between CSR and CFP. Secondly, this study expands information about CSR in different countries to scholars and researchers. It also contributes to investors, who consider CSR in decisions making process.

Key words: CSR, financial performance, ROA, ROE

\section{КОРПОРАТИВНА СОЦІАЛЬНА ВІДПОВІДАЛЬНІСТЬ ТА ФІНАНСОВІ РЕЗУЛЬТАТИ ДІЯЛЬНОСТІ: ВЗАСМОЗВ’ЯЗОК В РІЗНИХ КРАЇ̈АХ}

\footnotetext{
Це дослідження має на меті вивчити літературу про взаємозв'язок між корпоративною соціальною відповідальністю (КСВ) та фінансовими показниками в різних країнах. Були досліджені дослідження з дев'яти різних країн. Результати
}

(C) Botsian T. 
вказують на наявність трьох груп результатів. Можна виділити три різні типи зв'язків між КСВ та результатами діяльності: позитивні, негативні та нейтральні. Ми стверджсусо, щзо дослідники 9 різних країн використовують ичілком одну і ту ж методологію, щоб розглянути питання про зв'язок між КСВ та фінансовими показинками для різних типів компаній. На КСВ впливає культурне та соціальноекономічне середовище, а також начіональна система бізнесу. Політичні інститути також є потениійними рушіями КСВ. Крім того, неформальні установи, такі як національні культури, мають вплив на КСВ. Національна бізнес-система конкретної краӥни створює умови, за яких підприємства з більшою чи меншою ймовірністю застосовують соціально-відповідальну поведінку. Наприклад, у краӥнах, щуо мають високий ступінь впливу профспілок, фірми працюють краще за соиіальними та екологічними показниками. Отже, різноманітність законодавчої бази та національні інститути (політичні, ринкові, культурні) є рушійними силами КСВ. Вони є специифічними для кожної країни. Завдяки изьому всі досліджені звязків КСВ та фінансових показинків є непорівнюваними через різницю в національних інститутах, щэо впливаютьна соиіально- відповідальну поведінку компаній. Результати в одній краӥні можуть різнитисть від результатів в іншій краӥні. Це дослідження доповнює попередні дослідження, які вивчають відносини між корпоративною соціальною відповідальністю та фінансовими результатами. Значення дослідження полягає в тому, щзо воно, по-перше, розширює розуміння взаємозв'язку між КСВ та результатами діяльності; а по-друге, ие дослідження доповнює інформацію про КСВ у різних краӥнах для науковиів та дослідників. Дослідження також може допомогти інвесторам, які враховують КСВ у прочесі прийняття рішень.

Ключові слова: КСВ, фінансова діяльність, рентабельність активів, рентабельність власного капіталу

Introduction. It is widely recognized that people judgment of corporations depends upon actions toward business consciousness and awareness of social needs. It is resulting in a powerful trend concerns with Corporate Social Responsibility (CSR).

As far as CSR underpins the objectives of the Europe 2020 strategy for smart, sustainable and inclusive growth more and more documents appears, that direct and measure acts of socially responsible businesses. UN GPRF [28] provides straight forward guidance for companies to report on how they respect human rights. IRIS [14] issued by The Global Impact Investing Network for measurement practices across the impact investment industry. IRIS is the list of generally-accepted KPI to measure social, environmental, and financial success, evaluate deals, and grow the credibility of the impact investing industry. We also can remind GRI standards.

(c) Botsian T. 
However, to make CSR more strict EU affects crucial aspects of business by legislative changes. European Parliament approved at the end of 2014 The Directive [9] on disclosure of nonfinancial and diversity information, that became a basis for European Action Plan on Integrated Performance and Reporting and should be implemented in national laws of EU states. It becomes the 1st legislative act that makes firms to prepare non-financial statements. All documents issued by EU before it, were in the form of recommendations.

Despite of legislative regulation of CSR companies are doubtful about the nature of CSR. Is it an investment or expenditure? The answer to this question is so significant, that a huge number of works dedicated to the relationship between CSR and Corporate Financial Performance (CFP) all over the world.

Literature review. The topic of disclosure the relation between CSR and financial performance is extremely popular.

There has been more than 30 years of research and more than 100 empirical studies on the issue of the relationship between CSR reporting and financial performance, the findings have been mixed (Garcia-Castro et al., 2010). In a review of 127 previous studies, Margolis and Walsh (Margolis and Walsh, 2003) found that 109 studies treated CSR reporting as an independent variable in order to investigate if it was predictive of company's financial performance. They found the next:

1) number of studies, that indicated a significant positive relationship 54

2) number of studies, that showed a significant negative relationship -27 ;

3) number of studies, that revealed a non-significant relationship - 28.

Therefore, there have been three quite different results in studies seeking a relationship between CSR and corporate performance; a positive, a negative and no relationship. 
The same conclusion was made by Crisóstomo (Crisóstomo et al. 2011), who implies the existence of three-dimensional (positive, negative and neutral) arguments concerning the relationship between CSR and FCP.

Allouche and Laroche (2006) identified the results of 93 empirical studies on the relationship between CSR and FCP. The greatest part of these studies analyzed (49 from 93 studies which makes 52.68\%) shows a positive relationship between social performance and financial performance, whatever the financial criteria used.

We also found quite interesting the article by M. Mikołajek-Gocejna (Mikołajek-Gocejna, 2016), who examined correlations between CSR and FCP, based on empirical studies conducted by other authors in different countries. In total, the analysis comprises 53 studies and the results obtained for 16,119 companies. Correlations between CSR and corporate performance author grouped into four categories: positive, neutral, negative, and mixed.

Research question. Decades of research on CSR relationship with CFP have shown that it vary across the countries and can be weaker or stronger from country to country. Despite the trend towards extending the concept of CSR globally the question about the relationship' variety between CSR and CFP is not revealed enough.

The main objective of the study is to test this relationship taking into account practice in different countries

Methodology. This analysis of the correlation between CSR and CFP performance is based on the examining of literature studies.

Results and Discussions. First of all, we to conduct research of the publications dedicated to the relationship between CSR and CFP in different counties. The works describe the situation in specific country.

1. India

The article (Gautam, Richa; Singh, Anju; Bhowmick, Debraj 2016) explores the relationship between financial and social performance of a sample (C) Botsian T. 
of 500 Indian companies. Authors measure CFP by accounting-based measures such as Return on Capital Employed (ROCE), ROA and Profit after Tax (PAT) for company's financial performance. The CSR is disclosed by weighted average of company score after content analysis + Karmayog score). Regression analysis was employed to examine the relationship.

In summary the authors claimed that better financial performance results in improved CSR and positive relationship was found between indicators of financial performance and CSR disclosure. So, "improved CSR leads to better financial performance" stated authors.

In the study (Bedi, Harpreet Singh, 2009) top 1000 firms are examined for the financial year 2007-08 have been examined.

The analysis reveals that there is a positive relationship between CSR and financial performance and the descriptive and inferential measures shows that Corporate social expenditure depends upon the financial performance of the Company. But at the same time, we can conclude that most of the top Indian companies are spending nothing on part of their social responsibilities.

2. Jordan

The aim the study (Weshah, S., Dahiyat, A., Awwad, M., Hajjat, E. 2012), is to examine the relationship between CSR and Corporate Financial Performance among other factors.

In this study Corporate Financial is measured by ROA, while CSR is measured by the ratio of the amount of donation disclosed to interest revenue plus the ratio of training expenses to interest revenue

In the summary authors claims, that Depending on the statistical analytical plus simple and multiple regressions, using SPSS, they found that there is a significant relationship between the levels of bank's CSR and the bank's CFP.

3. Pakistan.

The paper (Waheed, R., Lv, Y., Sarwar, S., \& Sarwar, H., 2016) investigates the impact of corporate social responsibility on firms financial (c) Botsian T. 
performances in Pakistan. The data of 50 companies listed in Karachi stock exchange are used over the period 2005-2013. ROE and ROA are used as a proxy of company's financial performance. Whereas, community performance, environment management system and employee relations are taken as a proxy of CSR.

In the conclusion authors state that the community performance, environment management system and employee relations confirm significant positive relationship with ROE. The community performance confirms a significant positive relationship with ROA; environment management system proves significant positive; on contrary, employee relation is insignificant and has no role in firms' financial performances. The results conclude the significant role of CSR on the firms' financial performance in developing countries.

The same time the paper (Iqbal, N., Ahmad, N., Basheer, N. A., \& Nadeem, M., 2012) devoted to the relationship of CSR, financial performance and market value of the share and financial leverage showed quite different results. In this study 156 listed companies on Karachi Stock Exchange from textile sector, chemical sector, cement sector and the tobacco sector are taken. The observations was taken for 2010 and 2011.

For CSR indication authors used weighted index, which includes nine parameters: corporate governance, business ethical principles, environmental compliance, social compliance, disclosure environmental and social report, product integrity, corporate giving's and community investment, stakeholders dialogue and supply chain security. To compute relationship between the CSR and financial performance, we excluded the score of financial performance to avoid the similarity in data problem. To compute the CFP ROE and ROA were used.

The results of the study conclude that CSR has no effect on CFP. Moreover, in this study CSR has negative effect on the market value of the share, but no relationship to financial leverage of the firm. 


\section{Nigeria}

On the contrast to many other countries, many researches have been conducted in Nigeria. Most of them examine different industries, although the most popular is pharmaceutical industry in Nigeria.

Mba (2006) examined the impact of CSR on financial performance of quoted companies in Nigeria. The study results revealed the negative relationship between CSR and ROE as well as Chand (2006).

The study (Muhammad Shaheer Nuhu, Sani Salisu, 2017) examines the effects of CSR on financial performance of quoted pharmaceutical companies in Nigeria for 10 years period (2006-2015).

The study examined the effect between profitability, firm size, corporate tax and CSR focusing on the Nigerian marketing petroleum and food and beverages sector. The population of this study comprises of marketing petroleum and food and beverages companies that are listed in the Nigerian Stock Exchange.

Data were collected from the annual report and accounts of the selected companies. Using the profit before tax and interest, tax paid and the annual turnover as proxies for profitability, corporate tax and firm size respectively. The results revealed a significant positive effect between profitability, corporate tax and CSR. The result of the study shows a significant negative effect between firm size and CSR.

\section{Egypt}

The paper (Basuony, M. A. K., Elseidi, R. I., \& Mohamed, E. K. A., 2014) investigates the CSR on organization performance in Egypt.

CSR in this research consists of four dimensions which are economic, ethical, legal and discretionary dimensions. Firm size, firm age and type of industry are the control variables used in this framework. Firm performance in this work is represented by ROA, ROE, return on sales (ROS), competitive position and sales growth 
The findings of this study found that there is a positive and significant effect of CSR on firm performance. Also, all CSR dimensions have significant relationship with firm financial performance.

6. Thailand

The study's (Muttanachai Suttipun, 2014) objectives were to test the different levels of CSR reporting by companies listed on the Stock Exchange of Thailand between groups based on industry type, auditor type, and CSR award, and to test the relationships between corporate characteristics, CSR reporting, and financial performance. Full model of path analysis in this study reveals "CSR reporting as the dependent variable, and the corporate characteristics, industry type, auditor type, and CSR award as independent variables. Alternatively, with firm performance as the dependent variable, the corporate characteristics, and CSR reporting can be viewed as independent variables".

In the conclusion authors reveals significant relationship between industry type, the level of corporate social responsibility reporting, and financial performance. They found that it would be desirable to require mandatory CSR reporting by Thai listed companies., due to the the results showing a relationship between CSR reporting and company performance.

7. France

The impact of voluntary disclosure about CSR on firm's financial performance was investigate in the paper (Najah, Ahlem and Jarboui, Anis, 2013). The authors examined 201 big French companies over a period of 20002010.

Firm's financial performance was indicated by ROA and ROE. The Study focused on the CSR reports as a proxy of social performance.

The results showed that there is no significant relation between CSR disclosure and financial performance for French companies

8. UK 
The study (Adeneye, Y.B., Ahmed, M. (2015), examined the impact of CSR on company performance. A descriptive research design was adopted. Corporate social responsibility was measured using CSR index. Company performance was measured using market to book value (MBV), company size and return on capital employed (ROCE). 500 firms in the United Kingdom were examined in the paper.

Findings showed significant positive relationship between CSR, MBV and ROCE; however, no significant relationship between CSR and size of the firm was found.

9. Sri Lanka

The study (Hewage Rs, Wijesundara Cnr, Rasika Dgl, 2016) examines the impact of CSR on company financial performance.

CSR is estimated by three kind of activities: to environment, to employees and to community.

15 listed financial companies in Colombo Stock Exchange were examined for the period 2011 - 2014. Financial Performance was estimated through ROA and ROE. CSR was measured by ranking method of quantifying the CSR activities.

The results indicated that CSR has a significant influence on company financial performance.

According to our research of 9 different countries from different parts of the world, relationship between CSR and CFP can be divided into three different types of results: positive, negative or neutral. The main factor of such situation is a variety of legislative basis and national institutions (political, market, cultural) as drivers of CSR. They is a specific for each country. Some studies has shown the influence of the political environment (Bushman, Piotroski \& Smith, 2004), the legal environment, press diffusion (Dyck \& Zingales, 2004), and cultural heritage on corporate governance and CSR. 
CSR is strongly influenced by cultural and socio-economic environments (Aguilera, Rupp, Williams, \& Ganapathi, 2007; Matten \& Moon, 2008) and relates to a country's national business system.

Ioannis Ioannou and George Serafeim (2010) have argued for the importance of political institutions as potential drivers of CSR. They identify two fundamental institutional drivers in theoretical analysis: the level of corruption in the country, and the overarching ideological stigma of its government. Labor market institutions essentially act as a mechanism of structural truce. In countries with a high degree of union power, firms perform better on the social and environmental scores, since powerful unions may push for more benefits for employees, such as employees' health and safety provisions, workplace amenities, more socially responsible policies for local communities. Moreover, unions may even increase overall awareness of the firm's environmental policies to audiences outside the firm itself.

In such conditions, country's national business system creates the conditions under which corporations are more or less likely to engage in socially responsible behavior.

Moreover, informal institutions such as national cultures have an important effect on CSR practices. This is not surprising, as cultures are persistent and uniformly affect different aspects of organization behavior (e.g., adoption, engagement, and compliance), compared with more context-specific regulations and rules (Whitley, 1999).

Conclusions. This article adds to the previous research devoted to the relationship between corporate social responsibility and corporate financial performance. This study shows up that relationship between CSR and CFP in different countries can be divided into three different types of relationships: positive, negative and neutral.

The study claims, that researchers of 9 different countries use quite the same methodology to different types of companies to examine the relation (C) Botsian T. 
between CSR and CFP. However, all examined studies are incomparable due to the difference of the national institutions, which drives responsible behavior of the companies. The results in one country can be different in another.

The study contributes to the CSR literature in the following ways. Firstly, the study enhances understanding of the relationship between CSR and CFP. Secondly, this study expands information about CSR in different countries to scholars and researchers. It also contributes to investors, who consider CSR in decisions making process.

\section{REFERENCES}

1. Adeneye, Y.B., Ahmed, M. (2015). Corporate social responsibility and company performance. Journal of Business Studies Quarterly, 7(1), 151-166.

2. Aguilera, R.V., Rupp, D. E., Williams, C.A. and Ganapathi J. (2007). Putting the $\mathrm{S}$ back in corporate social responsibility: A multilevel theory of social change in organizations. The Academy of Management Review Vol. 32, No. 3, pp. 836-863.

3. Allouche José, Laroche Patrice (2005). A Meta-analytical investigation of the relationship between corporate social and financial performance. Revue de Gestion des Ressources Humaines, Eska, pp.18. ffhal-00923906f.

4. Basuony, M. A. K., Elseidi, R. I., \& Mohamed, E. K. A. (2014). The impact of corporate social responsibility on firm performance: Evidence form a MENA country. Corporate Ownership \& Control, 12(1-9), 761-774.

5. Bedi, Harpreet Singh, Financial Performance and Social Responsibility: Indian Scenario (October 29, 2009). Available at: https://ssrn.com/abstract=1496291 or http://dx.doi.org/10.2139/ssrn.1496291

6. Bushman, Robert M. and Piotroski, Joseph D. and Smith, Abbie J., What Determines Corporate Transparency (2004). Journal of Accounting Research, 42 (2). Available at: https://ssrn.com/abstract $=428601$, 
7. Chand, M. (2006). The relationship between corporate social performance and corporate financial performance: Industry Type as a 'Boundary Condition' Disclosure: Some Empirical Evidence. Accounting, Auditing and Accountability Journal, Vol.7, pg. 47,

8. Crisóstomo, V.L., Freire, F.S. and Vasconcellos, F.C. (2011). Corporate social responsibility firm value and financial performance in Brazil 'Social Responsibility Journal' Vol. 7 No. 2.

9. Directive 2014/95/EU of the European Parliament and of the Council of 22 October 2014 amending Directive 2013/34/EU as regards disclosure of nonfinancial and diversity information by certain large undertakings and groups Retrieved from: http://eur-lex.europa.eu/legalcontent/EN/TXT/?uri= OJ\%3AJOL_2014_330_R_0001.

10. Dyck, A. and Zingales, L. (2004). Private Benefits of Control: An International Comparison. The Journal of Finance, 59, 537-600.

11. Garcia-Gastro, R., Arino, M.A., and Canela, M.A. (2010). "Does social performance really lead to financial performance? Accounting for endogeneity", Journal of Business Ethics, Vol. 92, pp. 107-126.

12. Griffin, J. J., and Mahon, J. F. (1997). "The Corporate Social Performance and Corporate Financial Performance Debate: Twenty-Five Years of Incomparable Research," Business \& Society, Vol. 36, (5): 5-31. Available at: https://ssrn.com/abstract=2267176.

13. Griffin, Jennifer and Mahon, John F. (2013). The Corporate Social Performance and Corporate Financial Performance Debate: Twenty-Five Years of Incomparable Research (May 19, 2013).

14. Impact Reporting and Investment Standards Retrieved from: https://iris.thegiin.org/about-iris

15. Ioannou, I. and Serafeim, G. (2010). What Drives Corporate Social Performance? The Role of Nation-level Institutions. HBS Working Paper Series $11-016$.

(C) Botsian T. 
16. Iqbal, N., Ahmad, N., Basheer, N. A., \& Nadeem, M. (2012). Impact of corporate social responsibility on financial performance of corporations: Evidence from Pakistan. International Journal of Learning \& Development, 2(6).

17. Iqra A.M, Naeem A., Aqsa I. \& Ayesha (2014). Impact of Corporate Social Responsibility on Financial Performance: a Case Study of Pakistan. International Review of Management and Business Research Vol. 3 Issue.4, pp.1914-1927.

18. Gautam, Richa; Singh, Anju; Bhowmick, Debraj (2016). Demystifying relationship between corporate social responsibility (CSR) and financial performance: an Indian business perspective. Independent Journal of Management \& Production, vol. 7, núm. 4, pp. 1034-1062.

19. Margolis, J.D., and Walsh, J.P. (2003). "Misery loves companies: rethinking social initiatives by business", Administrative Science Quarterly, Vol. 48 No, 2, pp. 268-305.

20. Matten, D., \& Moon, J. (2008). "Implicit" and "explicit" CSR: A conceptual framework for a comparative understanding of corporate social responsibility. The Academy of Management Review, 33(2), 404-424.

21. Mba, T.A. (2006). The impact of Corporate Social Responsibility on Financial Performance of quoted companies in Nigeria: MBA thesis, Ambrose Alli University, Ekpoma.

22. McWilliams, A., \& Siegel, D. (2001). Corporate Social Responsibility: A Theory of Firm Perspective. Academy of Management Review, Vol.26. No. 1.

23. Mikołajek-Gocejna M. (2016). The relationship between social responsibility and corporate financial performance - Evidence from empirical studies. Comparative Economic Research, 19 (4), 67-83.

24. Muhammad Shaheer Nuhu, Sani Salisu (2017). Corporate Social Performance Determinants: A Study of Marketing Petroleum and Food and 
Beverages Industry in Nigeria International Journal of Business and Technopreneurship Volume 7, No. 3, 307-324.

25. Muttanachai Suttipun (2014). Corporate characteristics, social responsibility reporting, and financial performance: evidence in Thailand Corporate Ownership \& Control / Vol. 12, Issue 1, 836-847.

26. Najah, Ahlem and Jarboui, Anis (2013). The Social Disclosure Impact on Corporate Financial Performance: Case of Big French Companies International Journal of Business Management and Research, Vol. 3, No. 4. Available at: https://ssrn.com/abstract=2472347.

27. Ngwakwe, C.C. (2008). Environmental Responsibility and Firm Performance: Evidence from Nigeria. World Academy of Science, Engineering and Technology 462008.

28. Turban, D., \& Greenin, D. (1997). Corporate Social Performance and Organizational. Academy of Management Journal, Vol.40.658-672.

29. United Nations Guiding Principles Reporting Framework Retrieved from: http://www.ungpreporting.org/consult-the-reporting-framework/download-thereporting-framework/

30. Uz Zaman (2013). The Relationship between Corporate Social Responsibility and Firm Financial Performance: A Case of Pakistan. Journal of Basic and Applied. 3(11)34-45.

31. Waddock, S., \& Graves, S. (1997). The corporate social performancefinancial performance link. Strategic Management Journal, vol. 18, no. 4, pp. 303-319.

32. Waheed, R., Lv, Y., Sarwar, S., \& Sarwar, H. (2016). The Role of Corporate Social Responsibility on Firms Financial Performance in Pakistan. Elixir Management Arts, 98, 667-671.

33. Weshah, S., Dahiyat, A., Awwad, M., Hajjat, E. (2012). The impact of adopting corporate social responsibility on corporate financial performance: 
Evidence from Jordanian banks. Interdisciplinary Journal of Contemporary Research in Business, 4(5), 34-44

34. Whitley, Richard (1999). Divergent Capitalisms: The social structuring and change of business systems, Oxford: Oxford University Press 